\title{
THE USE OF COMPOSTING FOR THE TREATMENT OF ANIMAL BY-PRODUCTS: EXPERIMENTS AT LAB SCALE
}

Raquel Barrena ${ }^{\mathrm{a}}$, Adriana Artola ${ }^{\mathrm{a}}$, Felícitas Vázquez ${ }^{\mathrm{b} *}$, Antoni Sánchez $^{\mathrm{a}}$

a'Departament d'Enginyeria Química, Escola Tècnica Superior d'Enginyeria, Universitat Autònoma de Barcelona, 08193 Cerdanyola del Vallès, Spain.

Institute of Biotechnology and Biomedicine

Universitat Autònoma de Barcelona

08193 Cerdanyola del Vallès, Spain

Corresponding author: Felícitas Vázquez

Institute of Biotechnology and Biomedicine

Universitat Autònoma de Barcelona

08193 Cerdanyola del Vallès, Spain

Pre-print of Barrena Gómez, Raquel et al. «The use of composting for the treatment of animal by-products: Experiments at lab scale» in Journal of Hazardous Materials (Elsevier), Vol. 161, Issue 1 (January 2009), p. 380-386. The final version is available at DOI 10.1016/j.jhazmat.2008.03.109 


\section{Abstract}

Animal by-products (ABP), containing mainly rabbit and chicken carcasses were composted at laboratory scale. Results indicate that if proper conditions are used, wastes can be successfully composted and stabilised meeting current European hygienisation standards regarding the disposal of this type of wastes. During the process, temperatures above $60{ }^{\circ} \mathrm{C}$ were easily reached and maintained for 2 days at least, due to the high energy potential of these materials. However, care must be taken to ensure that these temperatures are reached in the entire reactor to guarantee proper hygienisation of the material. These high temperatures may bring about operational problems such as moisture losses due to the very high airflows required for their control. Biological activity indices, such as Respiration Index (RI) and Oxygen Uptake Rate (OUR) used for the monitoring of the process, were able to indicate potential and actual conditions within the composting reactor respectively.

Key words: animal by-products, stabilisation, composting, hygienisation, slaughterhouse solid waste. 


\section{INTRODUCTION}

In Spain, animal wastes have been traditionally disposed of by incineration or landfilling, little sustainable alternatives since they only allow for a low recovery of resources.

In the Regulation 1774/2002 of the European Parliament and of the Council of 3 October 2002, the European health rules concerning animal by-products not intended for human consumption were laid down [1]. According to this regulation, animal by-products $(\mathrm{ABP})$ are defined as entire bodies or part of animals or products of animal origin not intended for human consumption. This regulation classifies $\mathrm{ABP}$ into three different categories ranging from category 1 that includes ABP presenting a TSE (Transmissible Spongiform Encephalopathy) risk or an unknown risk or a risk related to treatment with illegal substances or to environmental contaminants, to category 3 that includes ABP derived from healthy animals. Category 3 wastes, considered as low risk materials, comprise: part of slaughtered animals, fit or unfit for human consumption but with no signs of diseases communicable to humans such as hides and skins, hooves and horns, pig bristles, feathers, blood, raw milk, shells, hatchery by-products, and cracked egg by-products, etc. Category 3 material is the largest ABP produced by far.

Regulation $1774 / 2002$ also establishes the type of disposal or process that ABP can undergo. In the case of category 3 materials, composting is one of the processes of choice. 
Composting is a biotechnological process by which different microbial communities convert organic wastes into a stabilised form. During the process, thermophilic temperatures arise because of the heat released due to biological activity. These temperatures are responsible for pathogen inactivation. Composting is an aerobic process that requires oxygen, optimal moisture and enough free air space (FAS) and $\mathrm{C} / \mathrm{N}$ ratio within certain limits [2]. Temperature is routinely chosen as the control variable because it is an indicator of the biological activity of the material. Oxygen and moisture content are also common control variables in the composting process.

According to the European legislation, the use of composting for the treatment of category $3 \mathrm{ABP}$ must meet the requirements shown in Table 1 to ensure the proper handling of the material. As it can be seen, the monitoring of the processing conditions is an important feature included in these requirements.

Although European legislation establishes that composting can be used for the treatment of category $3 \mathrm{ABP}$ and different literature reviews on the subject state the suitability of the process $[3,4]$, so far very few works describing its actual use for this purpose are found [5-7]. Most of the published work refers to the use of composting for the treatment of animal manure [8-11].

On this basis, the objective of this work has been the study of the composting of animal solid wastes. Due to the complexity of the material and the legal restrictions that apply to its treatment, different control strategies were used with the aim of finding the most suitable to meet the legal requirements and avoid 
operational problems such as odour emissions. During the process, different parameters were followed to investigate the development of the process.

\section{MATERIALS AND METHODS}

\subsection{Composting materials}

ABP from different small abattoirs and farms, managed at the composting plant located in Jorba (Barcelona, Spain) were used in this study. These wastes consisted mainly of poultry and rabbit entrails, carcasses and feathers.

A mixture of wood chips and yard waste was used as bulking agent. ABP and bulking agent were blended in a 1:2 volumetric ratio. Mixtures were prepared at the composting plant.

\subsection{Composter}

Two similar $100 \mathrm{~L}$ static composters were used for these studies. A schematic diagram is shown in Figure 1. Each reactor had four Pt-100 sensors (Desin mod. SR-NOH) evenly distributed for the monitoring of the temperature throughout the process. $\mathrm{O}_{2}$ and $\mathrm{CO}_{2}$ concentrations in interstitial air were monitored with an $\mathrm{O}_{2}$ sensor (Sensox, Sensotran Spain) and an infrared detector (Sensotran I.R., Sensotran Spain), respectively. Ammonia emissions were measured on-line using an electrochemical gas sensor (Bionics Instruments Co. mod. TX-FN, Japan). $\mathrm{O}_{2}, \mathrm{CO}_{2}$ and $\mathrm{NH}_{3}$ concentrations were measured in the air out flow of the composter. All sensors were connected to an 
in-house data acquisition system. Oxygen was controlled by means of a feedback oxygen control system that automatically supplied fresh air to the reactor when required. Air inlet was located at the bottom left of the reactor. Composter was placed on a scale (BACSA mod. 1200) for on-line weight monitoring.

\subsection{Static Respiration Indices (RI) estimation}

Static Respiration Indices of composting samples were obtained off-line at process temperature at sampling $\left(R I_{T}\right)$ and at the fixed temperature value of $37^{\circ} \mathrm{C}\left(\mathrm{RI}_{37}\right)$, according to the method described by Barrena et al. [12]. $\mathrm{RI} \mathrm{I}_{37}$ are commonly used to determine the degree of stability of a compost sample while $\mathrm{RI}_{\mathrm{T}}$ indicate the potential biological activity of the material. It is also generally considered that $\mathrm{RI}$ values below $1.0 \mathrm{mg} \mathrm{O}_{2} \mathrm{~g} \mathrm{OM}^{-1} \mathrm{~h}^{-1}$ (referred to organic matter) correspond to stable material [13].

\subsection{Oxygen Uptake Rate (OUR) and Respiration Quotient (RQ) estimation}

Oxygen Uptake Rate (OUR) also referred as Dynamic Respiration Index in the composting field and Respiratory Quotient (RQ) are customarily used for the online determination of the biological activity in aerobic process. OUR expressed as the amount of oxygen consumed per unit organic matter content of the sample per hour $\left(\mathrm{mg} \mathrm{O}_{2} \mathrm{~g} \mathrm{OM}^{-1} \mathrm{~h}^{-1}\right.$ ), was estimated according to the method described by Gea et al. [14].

Respiration Quotient (RQ) was determined on-line from the $\mathrm{O}_{2}$ and $\mathrm{CO}_{2}$ concentrations according to the expression: 


$$
R Q=\frac{\% \mathrm{CO}_{2 \text { out }}-\% \mathrm{CO}_{2 \text { in }}}{\% \mathrm{O}_{2 \text { in }}-\% \mathrm{O}_{2 \text { out }}}
$$

where $\% \mathrm{CO}_{2}$ and $\% \mathrm{O}_{2}$ are the respective measured percentage volume concentrations and subscript "in" and out" correspond to the inlet and outlet concentrations. $\mathrm{CO}_{2}$ in was assumed as negligible and $\mathrm{O}_{2}$ in as $20.9 \%$.

\subsection{Analytical methods}

Moisture, Dry Matter (DM), Organic Matter (OM), N-Kjeldahl, pH, fat content, and conductivity were determined according to standard procedures [15]. Carbon content was estimated according to the method described by Adams et al. [16].

Free Air Space (FAS) was estimated using an air picnometer built according to Oppenheimer et al. [17] and Agnew et al. [18].

Microbiological analyses were performed by an external laboratory using standard methods. Representative samples collected in sterile containers were used. Sampling procedure is explained latter.

\subsection{Composting experiments}

Different control strategies were assayed in order to find out the most suitable for the composting of ABP. In a first experiment (Experiment 1), the typical control strategy used in most composting plants was tested. In this scheme, the $\mathrm{O}_{2}$ concentration in the reactor was set between $10-14 \%$ to ensure aerobic conditions, no temperature control was used. In a second experiment (Experiment 2), temperature and $\mathrm{O}_{2}$ concentration were controlled by regulating 
the airflow inlet to maintain the $\mathrm{O}_{2}$ concentration inside the reactor between 10$14 \%$ and the temperature below $55^{\circ} \mathrm{C}$ after an initial high-temperature hygienisation period, where temperatures were allowed to reach temperatures above $70^{\circ} \mathrm{C}$. Temperature control was considered as the prior control. Experiments 1 and 2 were performed using freshly collected wastes coming from different batches. Experiments 3 and 4 were carried out in parallel using the same initial material to avoid the variability of these wastes and, in conditions resembling experiments 1 and 2 respectively. Air supply for experiments 3 and 4 was improved changing the air inlet to the reactor from a single air entrance to a multiple distribution system using perforated tubing.

Water content of the composting mixture was adjusted based on the results of the squeeze test, which was carried out every time a sample was taken. This assay is an empirical test routinely used in composting plants to determine the moisture of composting material along the process [15]. If the test indicated that humidity was low, water was sprayed all over the material and mixed thoroughly; the test was then repeated to verify that the moisture was within the desired levels. If it was not the case, the whole procedure was repeated until the right moisture was reached.

\subsection{Sampling method}

Sampling procedure was as follows: first, composter was opened and its contents mixed with a rake; then, several samples of about the same size were collected from different parts and different depths until a $1 \mathrm{~L}$ beaker was filled 
with sample. The whole procedure was performed as quickly as possible to minimise disturbances to the system.

\section{RESULTS AND DISCUSSION}

\subsection{Composition of $A B P$}

Table 2 shows the composition of the ABP used in this study. Freshly collected wastes were used for each experiment. It can be observed that their composition was quite different as they corresponded to different batches in the composting plant. As expected, they all have high organic matter and nitrogen contents. Small variations in these parameters were observed resulting in small differences in the initial $\mathrm{C} / \mathrm{N}$ ratios. Nevertheless, all $\mathrm{C} / \mathrm{N}$ ratios were very low. Fat contents had the highest differences. FAS determined for experiment 1 is also shown in Table 2, its value (54\%) indicated that this mixture was suitable for their potential treatment at industrial scale. FAS was not calculated for the other experiments since it was assumed that little changes would be expected.

\subsection{Experiment 1: $\mathrm{O}_{2}$ control}

Figure 2 shows the process evolution when an $\mathrm{O}_{2}$ control strategy was applied. Temperature measurements at different points inside the reactor are displayed. It can be seen that these profiles followed a typical composting pattern. Initially, there was a sharp temperature increase up to $70^{\circ} \mathrm{C}$. This temperature was reached in practically all the reactor, and kept for more than one hour. However, in the section closer to the air entrance ( $T$ bottom left) maximum temperature 
reached was $68^{\circ} \mathrm{C}$. Temperatures in the entire reactor were maintained above $60{ }^{\circ} \mathrm{C}$ for about 10 days then they started to drop off to the mesophilic range.

Microbiological analyses were performed to samples at different stages of the process to verify if the material had actually been sanitised. Results indicated that initially the material contained Enterobactericeae $\left(1.1 \cdot 10^{6} \mathrm{cfu} / \mathrm{g}\right)$ but no Salmonella (absence in $25 \mathrm{~g}$ ), and after 10 days of process none of them were detected. However, at the end of the process both Enterobactericeae and Salmonella were detected in amounts slightly over the legal limit $\left(5 \cdot 10^{2} \mathrm{cfu} / \mathrm{g}\right.$, and presence in $25 \mathrm{~g}$, respectively). The cause of the inconsistency of these results may be diverse. Absence of Salmonella at the beginning of the process is more likely to be an indication of the lack of representativeness of the sample used for the assay rather than its actual absence. Non-representative samples are a common problem faced when working with meat products and wastes because of the heterogeneity of the material [19]. Besides, Salmonella is usually present in materials such as ABP [20]. Moreover, the absence of Salmonella and Enterobactericeae after 10 days of process may suggest that the high temperatures reached during this period resulted in a correct hygienisation of the material. However, the occurrence of both types of microorganisms at the end of the process contradicted those results. The lack of representativeness of samples may also explain this inconsistency. In the case of Enterobactericeae, survival might be due either to external contamination during the handling of the material throughout the process or by cross-contamination with material that could not be properly sanitised (section closer to the air inlet or to the reactor walls) with lower maximum temperatures 
or a combination of both. Besides, the existence of thermotolerant strains of Bactericeae have also been reported [21]. Nevertheless, the suitability of using them as parameter to determine the efficiency of hygienisation is questionable since although they are usually associated with intestinal infections, they can be found in almost all natural habitats. In the case of Salmonella, the most probably cause of its survival might be the existence of areas within the reactor where temperature never reached a thermophilic stage such as those closer to the surface. Besides, it has been reported [22] that non-stable material can be easily re-contaminated by Salmonella.

Figure 2-B shows the profiles of the $\mathrm{O}_{2}$ and $\mathrm{CO}_{2}$ content of the exit gas, and of the $R Q$ all through the process. As it can be seen, $R Q$ values did not show big variations and corresponded to an aerobic process $(R Q<1)$ for the most part of the process excepting the first day where $R Q \approx 1$. This suggests that during this period biological activity and hence oxygen demand within the reactor was so high that oxygen supply was barely enough to fulfil this requirement.

Figure 2-C shows the OUR and $\mathrm{RI}_{\mathrm{T}}$ evolution using as a reference the temperature profile in the centre of the reactor. As observed, $\mathrm{RI} \mathrm{I}_{\mathrm{T}}$ values (indicative of the potential biological activity) were significantly higher than OUR values (indicative of the actual activity inside the reactor). This suggested that, although microbial activity in the reactor was high, it was not optimal, as OUR values should be closer to $\mathrm{RI}_{\mathrm{T}}$ if this were the case. High temperature was one of the factors that could be affecting activity as evidenced in Figure 2-C, where it can be seen that at day 5 temperature suddenly felt down. As a result, an 
increase in activity represented by an increase in $\mathrm{RI}_{\mathrm{T}}$ and OUR values was observed.

Characteristics of the starting and end materials are shown in Table 3. As it can be seen, organic matter and fat content decreased during the process, indicating thus that they had been degraded. However, final $\mathrm{RI}_{37}$ indicated that biological activity at the end of the process was still considerable, suggesting thus that further processing was still needed to reach an appropriate stability. Nitrogen content of the final material was high, although $20 \%$ losses were estimated. Losses were calculated from the difference between nitrogen content from the initial and end materials. These values are similar to those reported by Beck-Friis et al. [23] when composting the organic fraction of municipal wastes (24 - 33\%) at lab scale, and lower than those estimated by Ekling and Kirchmann [24] when composting the same material at industrial scale (50 $70 \%$ ). Ammonia emissions were $500-800 \mathrm{mg} \mathrm{NH}_{3} \mathrm{~m}^{-3}$ during the thermophilic stage. These values may be considered as high but they are related to the high nitrogen content of the initial material. $\mathrm{N}_{-} \mathrm{NH}_{4}{ }^{+}$content was high, as expected for a material with an elevated organic nitrogen content.

Final characteristics of the material, and information provided by the OUR and $\mathrm{RI}_{\mathrm{T}}$ suggested that conditions used in this experiment were not the most favourable for the development of the composting process. In consequence, a second experiment was designed to improve the process conditions by means of preventing temperatures reaching very high values since in this experiment it was observed that they negatively influence microbial activity. 


\subsection{Experiment 2: temperature and oxygen control}

Figure 3 shows the process evolution when a strategy combining temperature and oxygen control was used. Temperature profiles (Fig. 3-A) show a first stage where temperature increased above $60{ }^{\circ} \mathrm{C}$ with a short interval at $70{ }^{\circ} \mathrm{C}$ to meet the legal hygienic requirements [1]. Afterwards, it was possible to maintain temperatures below $55^{\circ} \mathrm{C}$ but very high airflows were needed. These high airflows (values above $10 \mathrm{~L} \mathrm{~min}^{-1}$ and occasionally up to $30 \mathrm{~L} \mathrm{~min}^{-1}$ were required compared to the $1 \mathrm{~L} \mathrm{~min}^{-1}$ used in experiment 1 ), together with the air distribution system of the reactor, triggered significant temperature gradients within the reactor. They were also the cause that temperature never reached the thermophilic range in the sections surrounding the air entrance (control was based on the temperature value at the centre of the reactor). As suggested by results from experiment 1 , high airflows required for temperature control result from the high energetic potential of the ABP. At industrial scale, negative effects resulting from the high flow rates such as moisture losses may be alleviated by recirculating the hot air leaving the reactor.

Microbiological assays were not performed for experiment 2 because no thermophilic temperatures were reached in different sections of the reactor.

Figure 3-B shows the $\mathrm{O}_{2}, \mathrm{CO}_{2}$ and $\mathrm{RQ}$ profiles along the process. It can be observed that the high airflow rates required during the first days resulted in high $\mathrm{O}_{2}$ levels within the reactor (around 20\%). In consequence, differences between inlet and outlet $\mathrm{O}_{2}$ concentrations were negligible and therefore, very difficult to detect and thus, $R Q$ values were very low and more important, $\mathrm{O}_{2}$ uptake could not be accurately determined which might affect OUR calculations. 
After the initial stage, $\mathrm{O}_{2}$ concentration was maintained between $12-14 \%$ for the most part of the process until the final stage were it increased again, as usually occurs when the composting process has finished. Big $\mathrm{O}_{2}$ oscillations observed in Figure 3-B were due to the entry of air required to maintain the temperature below $55^{\circ} \mathrm{C}$.

Figure 3-C shows the profiles of the temperature at the centre of the reactor and of the biological activity represented by $\mathrm{RI}_{\mathrm{T}}$ and $\mathrm{OUR}$. As in the first experiment, important differences are observed between $\mathrm{RI}_{\mathrm{T}}$ and OUR. Besides, OUR values were higher than in experiment 1 , which may indicate that process was taking place in better conditions. Higher potential biological activity $\left(R I_{T}\right)$ is observed when process temperature was around $55^{\circ} \mathrm{C}$. It decreased along the process and was similar to the actual activity at around the $10^{\text {th }}$ day of process.

Table 4 shows the characteristics of the material at the beginning and at the end of the process. It can be observed that an important reduction in the organic matter content especially in the fat content took place. It is also observed that nitrogen losses were around $16 \%$ although the final nitrogen percentage was high. Final $\mathrm{Rl}_{37}$ was $1.39 \mathrm{mg} \mathrm{O}_{2} \mathrm{~g}^{-1} \mathrm{OM} \mathrm{h}^{-1}$, which indicates that an important reduction in the biological activity happened during the process.

When results from experiments 1 and 2 are compared, it is evident that best performance was obtained with the latter. A more stable product was obtained in approximately the same time indicating thus that conditions were more suitable for development of microbial activity. However, it is important to take into account that the big temperature gradients developed in experiment 2 may 
result in different stabilisation degrees inside the reactor. Besides, it is also important to consider that the high airflows required for the temperature control bring about higher water requirements to maintain moisture within the optimal composting levels. $6 \mathrm{~L}$ of water were added in experiment 1 while in the case of experiment 2, $15 \mathrm{~L}$ were used and even so, moisture levels were below optimal at some points.

Another important difference between experiments 1 and 2 was the initial fat content of the material, $7.16 \%$ and $17.68 \%$ respectively. Gea et al. [25] observed that fat degradation has an important role in the preservation of high temperatures in the reactor with higher fat contents resulting in longer processes. However, in this case a more stable product was obtained in a shorter time from an initial material with higher fat content indicating thus that the control strategy used effectively improved the process despite the higher fat content.

Nevertheless, differences in the characteristics of the initial material made it difficult to compare both processes therefore it was decided to repeat both experiments starting in parallel using the same initial material. For these experiments, air distribution systems were changed as explained before, to minimise the occurrence of temperature gradients inside the reactors.

\section{Experiments 3 and 4}

Results of the composting experiments $3\left(\mathrm{O}_{2}\right.$ control) and 4 (temperature and $\mathrm{O}_{2}$ control) are shown in Figures 4 and 5 respectively. It can be observed that 
the change in air distribution systems significantly improved the temperature gradients inside the reactors.

Figure 4-A shows the temperature profile corresponding to the experiment with $\mathrm{O}_{2}$ control (experiment 3). Results indicate that temperatures were very high throughout the process, with values above $60{ }^{\circ} \mathrm{C}$ even after 20 days of process. $\mathrm{O}_{2}, \mathrm{CO}_{2}$ and $\mathrm{RQ}$ profiles are shown in Figure 4-B. It can be observed that $\mathrm{RQ}$ values tended to decrease with time and were around 0.6 at the end of the process. These results differ with the findings of other authors who indicate that $R Q$ generally tends to be stable $[13,26]$. Observed decrease may be indicative that biological activity was low and therefore, there was still biodegradable material at the end of the process. Figure 4-C shows the $\mathrm{RI}_{\mathrm{T}}$ and $\mathrm{OUR}$ estimated along the experiment. Evolution of these biological parameters was significantly different from experiment 1 . OUR profile suggests that the biological activity in the reactor was very low throughout the process while $\mathrm{RI}_{\mathrm{T}}$ did not appreciably change during the process. These results agree with the $R Q$ values estimated along the experiment. The most probably cause of this low activity and degradability was the moisture content of the material. As observed in Figure 4-A, for most part of the process moisture levels were very low with values even below the optimal for microbial activity. Moisture levels between 40-60 \% are recommended [2]. However, in this experiment it was between $25-35 \%$ during most of the time. It is worth mentioning that approximately $6 \mathrm{~L}$ of water were added during the process, the same volume as in experiment 1 , but it was evident that they were not enough to keep the appropriate moisture levels. High temperatures and flow rates were the cause of the unsuitable 
moisture content during this experiment. Besides, these results also evidenced that the squeeze test cannot be used for the monitoring of the moisture of ABP. Some authors $[27,28]$ emphasize that moisture content rather than temperature, is the most important parameter influencing microbial activity in the composting process. Besides, it is one of the key parameters for the correct sanitisation of the material [22]. Results obtained in this experiment stress the importance of monitoring and controlling moisture levels when working with materials with very high thermal potential.

Results from experiment 4 where temperature and $\mathrm{O}_{2}$ were controlled are shown in Figure 5. They indicate that OUR were higher than in the former experiments suggesting a higher biological activity. OUR values were in some cases above $4 \mathrm{mg} \mathrm{O}_{2} \mathrm{~g}^{-1} \mathrm{OM} \mathrm{h}^{-1}$ reaching in some cases the $\mathrm{RI}_{\mathrm{T}}$ values. Highest $\mathrm{RI}_{\mathrm{T}}$ was around $10 \mathrm{mg} \mathrm{O}_{2} \mathrm{~g}^{-1} \mathrm{OM} \mathrm{h}^{-1}$ a similar value to that of experiments 1 and 2. As process proceeded, a slight decrease in activity was observed however, its value was still above $4 \mathrm{mg} \mathrm{O}_{2} \mathrm{~g}^{-1} \mathrm{OM} \mathrm{h}^{-1}$ after more than 10 days of process. These values suggest that at that moment microbial activity was still important as also reflected by the temperature profile since it was above $45^{\circ} \mathrm{C}$ after 20 days of process.

Table 5 shows the final characteristics of the products of experiments 3 and 4 . It can be observed that very little changes occurred to the material used in experiment 3 . In this case, a small decrease in the fat content is observed with almost no weight reduction or nitrogen losses. Stability indices also indicate that the material was still unstable at the end of the process and confirm the information given by the biological parameters along the process. $\mathrm{NH}_{4}{ }^{+}$content 
is higher that in the other experiments, which also indicates the low stability of the material [2]. In the case of experiment 4 , an important fat and organic matter reduction took place compared to experiment 3 , which was corroborated by the final stability index value $\left(\mathrm{RI}_{37}\right)$ and the high biological activity throughout the process.

Results indicate that although processes were not carried out under optimal conditions, it is worth remarking the sensitivity and usefulness of the biological activity indices. They were able to detect the low degradability reached at the end of the process while temperature profile corresponded to a typical composting process. Low moisture levels within the reactor were also reflected in the big differences found between $\mathrm{RI}_{\mathrm{T}}$ and $\mathrm{OUR}$. The former are estimated at optimal conditions while the latter represent the actual process conditions.

\section{CONCLUSIONS}

Meat solid wastes can be successfully composted if the right conditions are found. Temperatures above $70^{\circ} \mathrm{C}$, mandatory for the sanitation of the material are easily reached however; care must be taken to prevent big temperature gradients that may interfere with the correct hygienisation of the material. Moreover, handling of the materials plays an important role for pathogen control; contact between starting and finished materials should be avoided and tools used handling should not be shared. On the contrary, the high temperatures that can be reached and the high air requirements for its control may lead to problems with the moisture levels of the material. A good control of 
the process is required to maintain working conditions, temperature, aeration and moisture, within optimal limits. A first stage in a self-contained reactor such as a packed bed or covered piles may be required for the appropriate processing of the material. Results also show the convenience of using biological activity indices for the monitoring of the process since they have proven to be suitable to represent the actual conditions within the reactor.

\section{Acknowledgments}

The financial support from the Spanish Ministerio de Educación y Ciencia is acknowledged (Project CTM2006-00315).

\section{REFERENCES}

[1] European Union, Regulation (EC) No 1774/2002 of the European Parliament and of the Council of 3 October 2002 laying down health rules concerning animal by-products not intended for human consumption (2002) URL http://europa.eu/scadplus/leg/en/lvb/f81001.htm

[2] R.T. Haug, The practical handbook of compost engineering, Lewis Publishers, Boca Raton, FI, 1993.

[3] A. Kalbasi, S. Mukhtar, S.E. Hawkins, B.W. Auvermann, Carcass composting for management of farm mortalities: a review, Compost Sci. Util. 13 (2005) 180-193. 
[4] J. Bonhotal, L. Telega, J. Petzen, Natural rendering: composting livestock mortality and butcher waste, Cornell Waste Management Institute Fact Sheet 2, New York, 2002. URL http://cwmi.css.cornell.edu

[5] P.H. Liao, A.C. May, S.T. Chieng, Monitoring process efficiency of a fullscale in-vessel system for composting fisheries wastes, Biores. Technol. 54 (1995) 159-163.

[6] P.H. Liao, L. Jones, A.K. Lau, S. Walkemeyer, B. Egan, N. Holbek, Composting of fish wastes in a full-scale in-vessel system, Biores. Technol. 59 (1997) 163-168.

[7] F. Laos, M.J. Mazzarino, I. Walter, L. Roselli, P. Satti, S. Moyano, Composting of fish offal and biosolids in northwestern Patagonia, Biores. Technol. 81 (2002) 179-186.

[8] S. Goyal, S.K. Dhull, K.K. Kapoor, Chemical and biological changes during composting of different organic wastes and assessment of compost maturity, Biores. Technol. 96 (2005) 1584-1591.

[9] E. Guerra-Rodríguez, M. Vázquez, M. Díaz-Raviña, Dynamics of the composting of barley waste with liquid poultry manure, J. Sci. Food Agric. 83 (2003) 166-172.

[10] F. Miyatake, K. Iwabuchi, Effect of high compost temperature on enzymatic activity and species diversity of culturable bacteria in cattle manure compost, Biores. Technol. 96 (2005) 1821-1825. 
[11] F. Miyatake, K. Iwabuchi, Effect of compost temperature on oxygen uptake rate, specific growth rate and enzymatic activity of microorganisms in dairy cattle manure, Biores. Technol. 97 (2006) 961-965.

[12] R. Barrena Gómez, F. Vázquez Lima, M.A. Gordillo Bolasell, A. Sánchez Ferrer, Respirometric assays at fixed and process temperatures to monitor composting process, Biores. Technol. 96 (2005) 1153-1159.

[13] R. Barrena, F. Vázquez, A. Sánchez, The use of respiration indices in the composting process: a review, Waste Manage. Res. 24 (2006) 37-47.

[14] T. Gea, R. Barrena, A. Artola, A.Sanchez, Monitoring the biological activity of the composting process: Oxygen Uptake Rate (OUR), Respirometric Index (RI), and Respiratory Quotient (RQ), Biotechnol. Bioeng. 88 (2004) $520-527$.

[15] US Department of Agriculture, US Composting Council, Test Methods for the Examination of Composting and Compost (TMECC), Edapho International, Houston, Tx, 2002.

[16] R.C. Adams, F.S. MacLean, J.K. Dixon, F.M. Bennett, G.I. Martin, R.C. Lough, The utilization of organic wastes in N.Z.: Second interim report of the inter-departmental committee, New Zealand Eng. 15 (1951) 396-424.

[17] J. Oppenheimer, J. Martin, L. Walker, Measurements of air-filled porosity in unsaturated organic matrices using a pycnometer, Biores. Technol. 59 (1997) 241-247. 
[18] J.M. Agnew, J.J. Leonard, J. Feddes, Y. Feng, A modified air picnometer for compost air volume and density determination, Canadian Biosystems Eng. 45 (2003) 6.27-6.35.

[19] D.L. Fletcher, Influence of sampling methodology on reported incidence of Salmonella in poultry, J. AOAC Int. 89 (2006) 512-516.

[20] E.R. Haapapuro, N.D. Barnard, M. Simon, Review - animal waste used as livestock feed: dangers to human health. Preventive Medicine 26 (1997) 599-602.

[21] G. Salvat, P. Coppen, J.C. Allo, S. Fenner, M.J. Laisney, M.T. Toquin, F. Humbert, P. Colin, Effects of AvGard (TM) treatment on the microbiological flora of poultry carcases, British Poultry Sci. 38 (1997) 489-498.

[22] P. Jones, M. Martin, A review of the literature on the occurrence and survival of pathogens of animals and humans in green compost. Research report, The Waste and Resources Action Program, Banbury, UK, 2003.

[23] B. Beck-Friis, S. Smars, H. Jönsson, H. Kirchmann, Gaseous emissions of carbon dioxide, ammonia and nitrous oxide from organic household waste in a compost reactor under different temperature regimes, J. Agric. Eng. Res. 78 (2001) 423-430.

[24] Y. Eklin, H. Kirchmann, Composting and storage of organic household waste with different litter amendments ii: nitrogen turnover and losses, Biores. Technol. 74 (2000) 124-133. 
[25] T. Gea, P. Ferrer, G. Alvaro, F. Valero, A. Artola, A. Sánchez, Cocomposting of sewage sludge:fat mixtures and characteristics of the lipases involved, Biochem. Eng. J. 33 (2007) 275-283.

[26] M. Klauss, E.K. Papadimitriou, Determining the degree of aerobiosis in composting material, Bioprocessing Solid Waste Sludge 2 (2002) 37-47.

[27] R. Margesin, J. Cimadom, F. Schinner, Biological activity during composting of sewage sludge at low temperatures, Int. Biodet. Biodegrad. 57 (2006) 88-92.

[28] C. Liang, K.C. Das, R.W. McClendon, The influence of temperature and moisture content regimes on the aerobic microbial activity of a biosolids composting blend, Biores. Technol. 86 (2003) 131-137. 
Table 1. Main legal requirements for the composting of category 3 animal byproducts (ABP) according to the European Legislation.

\begin{tabular}{|l|l|}
\hline & Requirements \\
\hline Premises & $\begin{array}{l}\text { Installations for monitoring temperature against time } \\
\text { Recording devices to record the results of these measurements, } \\
\text { An adequate safety system to prevent insufficient heating } \\
\text { Adequate facilities for cleaning and disinfecting vehicles and } \\
\text { containers transporting untreated animal by-products }\end{array}$ \\
\hline $\begin{array}{l}\text { Processing } \\
\text { standards }\end{array}$ & $\begin{array}{l}\text { Maximum particle size entering the composting reactor: } 12 \mathrm{~mm} \\
\text { Minimum temperature in all material in the reactor: } 70 \text { ㅇ C } \\
\text { Minimum time in the reactor at } 70 \text { ㅇ: } 60 \text { min }\end{array}$ \\
\hline $\begin{array}{l}\text { Product } \\
\text { (compost) }\end{array}$ & $\begin{array}{l}\text { Salmonella: absence in } 25 \mathrm{~g} \\
\text { Enterobactericeae: } 300 \text { in } 1 \mathrm{~g}\end{array}$ \\
\hline
\end{tabular}


Table 2. Initial characteristics of the ABP used in this study.

\begin{tabular}{|c|c|c|c|}
\hline Characteristic & $\begin{array}{l}\text { Experiment } \\
1\end{array}$ & $\begin{array}{l}\text { Experiment } \\
2\end{array}$ & $\begin{array}{l}\text { Experiments } \\
3 \& 4\end{array}$ \\
\hline Moisture (\%) & 41.63 & 49.31 & 46.76 \\
\hline 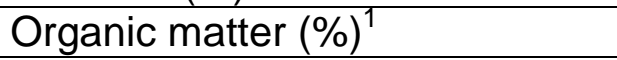 & 62.08 & 67.73 & 72.92 \\
\hline $\mathrm{pH}$ & 8.59 & 8.35 & 7.67 \\
\hline Electrical conductivity $\left(\mathrm{mS} \mathrm{cm}^{-1}\right)$ & 5.63 & 4.70 & 6.23 \\
\hline N-Kjeldahl $(\%)^{1}$ & 4.18 & 5.04 & 7.33 \\
\hline N-Kjeldahl (kg) & 0.93 & 0.80 & 1.03 \\
\hline $\mathrm{C} / \mathrm{N}$ & 8.25 & 7.47 & 5.53 \\
\hline $\mathrm{NH}_{4}^{+}(\%)^{1}$ & 0.54 & 0.81 & 0.88 \\
\hline FAS (\%) & 54.20 & & \\
\hline Fat $(\%)^{1}$ & 7.16 & 17.68 & 11.8 \\
\hline $\mathrm{RI}_{37}\left(\mathrm{mg} \mathrm{O}_{2} \mathrm{~g}^{-1} \mathrm{OM} \mathrm{h}^{-1}\right)$ & 2.42 & 4.87 & 6.51 \\
\hline
\end{tabular}

${ }^{1}$ expressed on dry weight basis 
Table 3. Initial and final characteristics of the composted material when oxygen concentration in the reactor was controlled (Experiment 1).

\begin{tabular}{|c|c|c|}
\hline Characteristic & Initial & Final \\
\hline Moisture (\%) & 41.63 & 49.40 \\
\hline 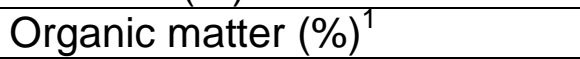 & 62.08 & 58.56 \\
\hline $\mathrm{pH}$ & 8.59 & 8.63 \\
\hline $\begin{array}{l}\text { Electrical conductivity }\left(\mathrm{mS} \mathrm{cm}^{-}\right. \\
\text {1) }\end{array}$ & 5.63 & 5.05 \\
\hline N-Kjeldahl $(\%)^{1}$ & 4.18 & 4.38 \\
\hline N-Kjeldahl (kg) & 0.93 & 0.73 \\
\hline $\mathrm{C} / \mathrm{N}$ & 8.25 & 7.42 \\
\hline $\mathrm{NH}_{4}^{+}(\%)^{1}$ & 0.54 & 0.62 \\
\hline FAS (\%) & 54.20 & 62.48 \\
\hline Fat $(\%)^{1}$ & 7.16 & 2.49 \\
\hline $\mathrm{RI}_{37}\left(\mathrm{mg} \mathrm{O}_{2} \mathrm{~g}^{-1} \mathrm{OM} \mathrm{h}^{-1}\right)$ & 2.42 & 1.75 \\
\hline
\end{tabular}


Table 4. Initial and final characteristics of the composted material when oxygen concentration in the reactor and temperature were controlled (Experiment 2).

\begin{tabular}{|c|c|c|}
\hline Characteristic & Initial & Final \\
\hline Moisture (\%) & 49.31 & 47.40 \\
\hline 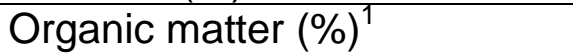 & 67.73 & 59.68 \\
\hline $\mathrm{pH}$ & 8.35 & 8.89 \\
\hline $\begin{array}{l}\text { Electrical conductivity }\left(\mathrm{mS} \mathrm{cm}^{-}\right. \\
\text {1) }\end{array}$ & 4.70 & 5.11 \\
\hline N-Kjeldahl $(\%)^{1}$ & 5.04 & 4.97 \\
\hline N-Kjeldahl (kg) & 0.80 & 0.67 \\
\hline $\mathrm{C} / \mathrm{N}$ & 7.47 & 6.67 \\
\hline $\mathrm{NH}_{4}^{+}(\%)^{1}$ & 0.81 & 0.65 \\
\hline Fat $(\%)^{1}$ & 17.68 & 4.10 \\
\hline $\mathrm{RI}_{37}\left(\mathrm{mg} \mathrm{O}_{2} \mathrm{~g}^{-1} \mathrm{OM} \mathrm{h}^{-1}\right)$ & 4.87 & 1.39 \\
\hline
\end{tabular}


Table 5. Characteristics of the initial and final material for experiments with oxygen control and, oxygen and temperature control and improved air distribution system.

\begin{tabular}{|c|c|c|c|}
\hline Characteristic & Initial & $\begin{array}{l}\text { Oxygen } \\
\text { control } \\
\text { (Experiment } \\
\text { 3) }\end{array}$ & $\begin{array}{l}\text { Oxygen and } \\
\text { temperature } \\
\text { control } \\
\text { (Experiment 4) }\end{array}$ \\
\hline Moisture (\%) & 46.76 & 26.12 & 33.38 \\
\hline 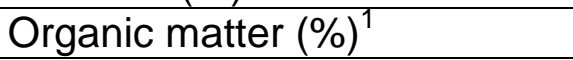 & 72.92 & 70.88 & 60.73 \\
\hline $\mathrm{pH}$ & 7.67 & 8.19 & 8.33 \\
\hline $\begin{array}{l}\text { Electrical conductivity }\left(\mathrm{mS} \mathrm{cm}^{-}\right. \\
1 \text { ) }\end{array}$ & 6.23 & 5.00 & 4.24 \\
\hline N-Kjeldahl $(\%)^{1}$ & 7.33 & 5.77 & 5.31 \\
\hline N-Kjeldahl (kg) & 1.03 & 1.02 & 0.86 \\
\hline $\mathrm{C} / \mathrm{N}$ & 5.53 & 6.83 & 6.36 \\
\hline $\mathrm{NH}_{4+}(\%)^{1}$ & 0.88 & 0.71 & 0.45 \\
\hline Fat $(\%)^{1}$ & 11.8 & 9.58 & 2.92 \\
\hline $\mathrm{RI}_{37}\left(\mathrm{mg} \mathrm{O}_{2} \mathrm{~g}^{-1} \mathrm{OM} \mathrm{h}^{-1}\right)$ & 6.51 & 2.88 & 1.62 \\
\hline
\end{tabular}

${ }^{1}$ expressed on dry weight basis 


\section{Legends to figures}

Figure 1. Schematic diagram of the composter rig used for this work.

Figure 2. Experiment 1: composting of $\mathrm{ABP}$ using an oxygen control strategy.

A) Temperature profile in different reactor sections, moisture content and airflow inlet. B) $\mathrm{O}_{2}$ and $\mathrm{CO}_{2}$ concentration and Respiratory Quotient (RQ). C) Temperature at the centre of the reactor, Respiration Index at sampling temperature $\left(\mathrm{RI}_{\mathrm{T}}\right)$, and Oxygen Uptake Rate (OUR).

Figure 3. Experiment 2: composting of ABP using a temperature control strategy. A) Temperature profile in different reactor sections, moisture content and airflow inlet. B) $\mathrm{O}_{2}$ and $\mathrm{CO}_{2}$ concentration and Respiratory Quotient (RQ). C) Temperature at the centre of the reactor, Respiration Index at sampling temperature $\left(R I_{T}\right)$, and Oxygen Uptake Rate (OUR).

Figure 4. Experiment 3: composting of ABP using an oxygen control strategy with improved aeration system. A) Temperature profile in different reactor sections, moisture content and airflow inlet. $\mathrm{B}) \mathrm{O}_{2}$ and $\mathrm{CO}_{2}$ concentration and Respiratory Quotient (RQ). C) Temperature at the centre of the reactor, Respiration Index at sampling temperature $\left(\mathrm{RI}_{\mathrm{T}}\right)$, and Oxygen Uptake Rate (OUR).

Figure 5. Experiment 4: composting of $A B P$ using a temperature control strategy with improved aeration system. A) Temperature profile in different reactor sections, moisture content and airflow inlet. B) $\mathrm{O}_{2}$ and $\mathrm{CO}_{2}$ concentration and Respiratory Quotient (RQ). C) Temperature at the centre of the reactor, Respiration Index at sampling temperature $\left(R I_{T}\right)$, and Oxygen Uptake Rate (OUR). 
Figure 1.

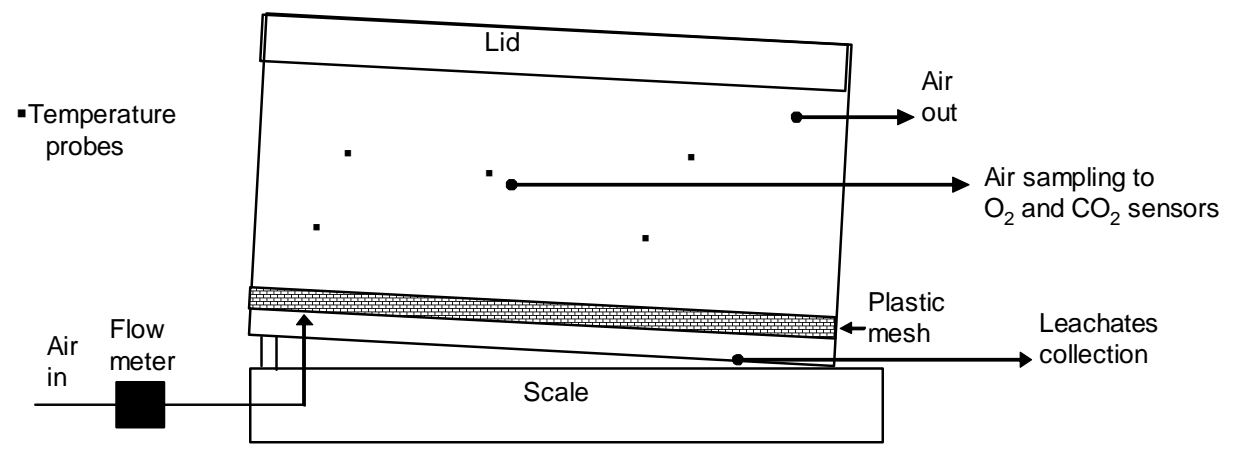


Figure 2.
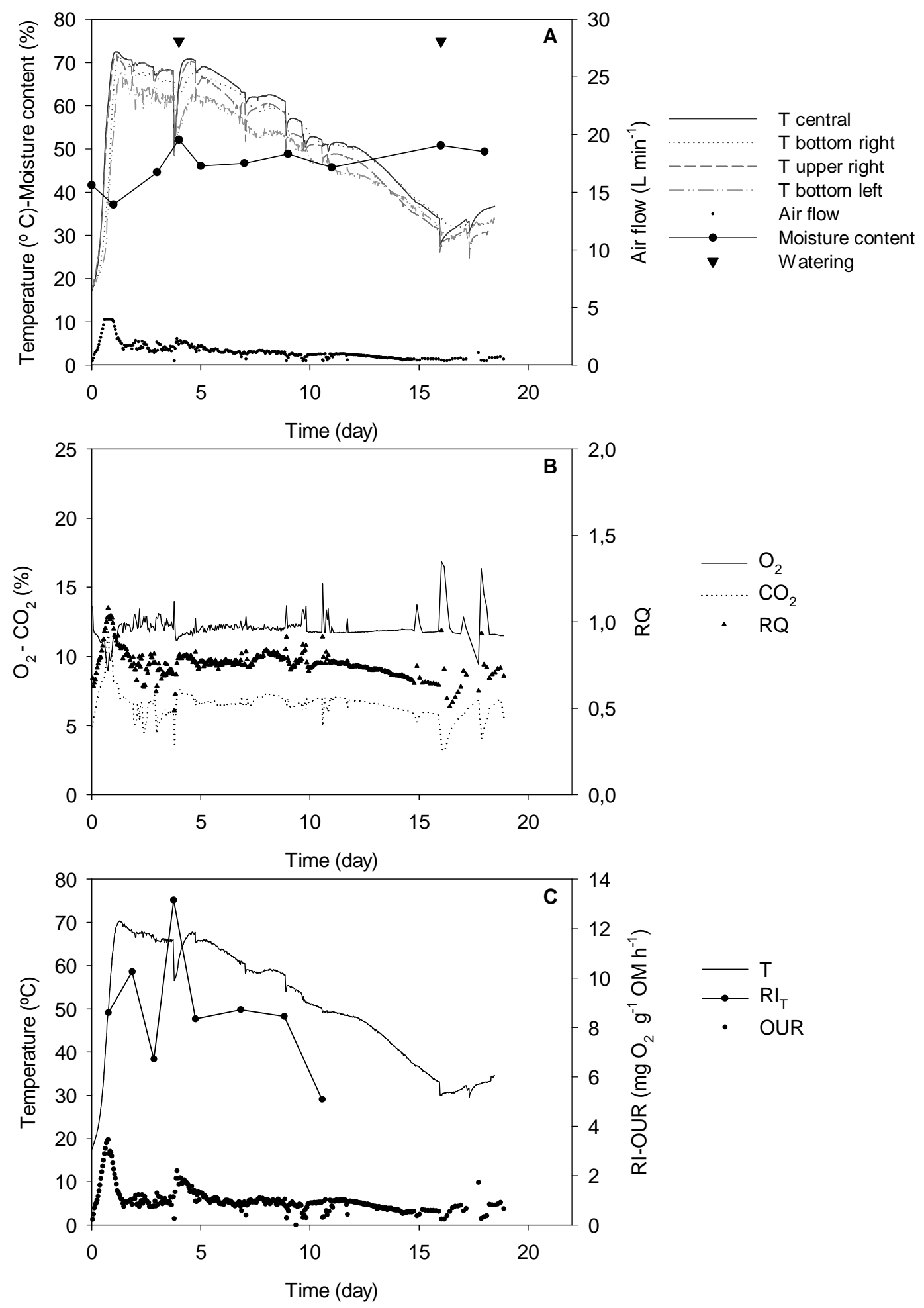
Figure 3.
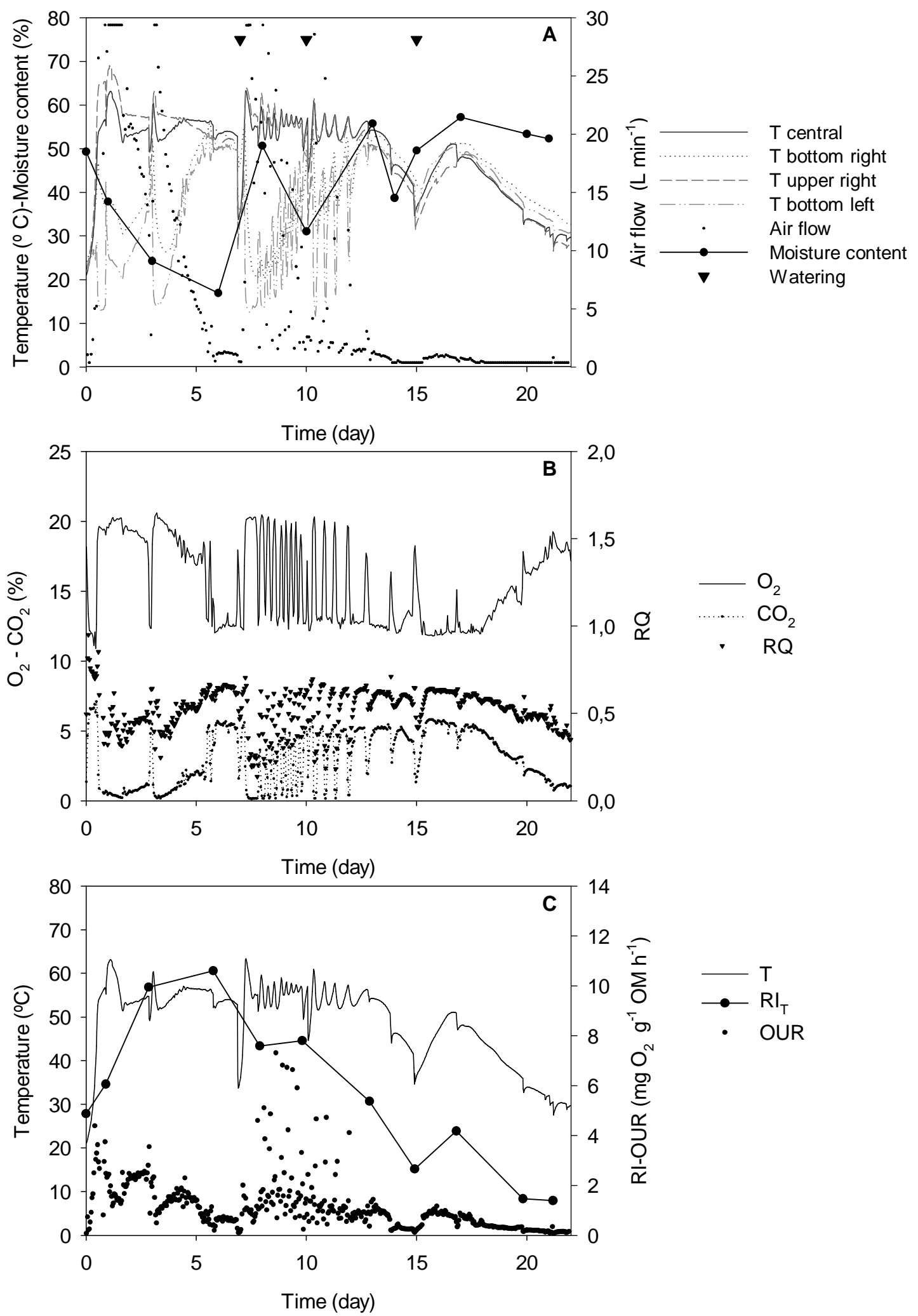
Figure 4.
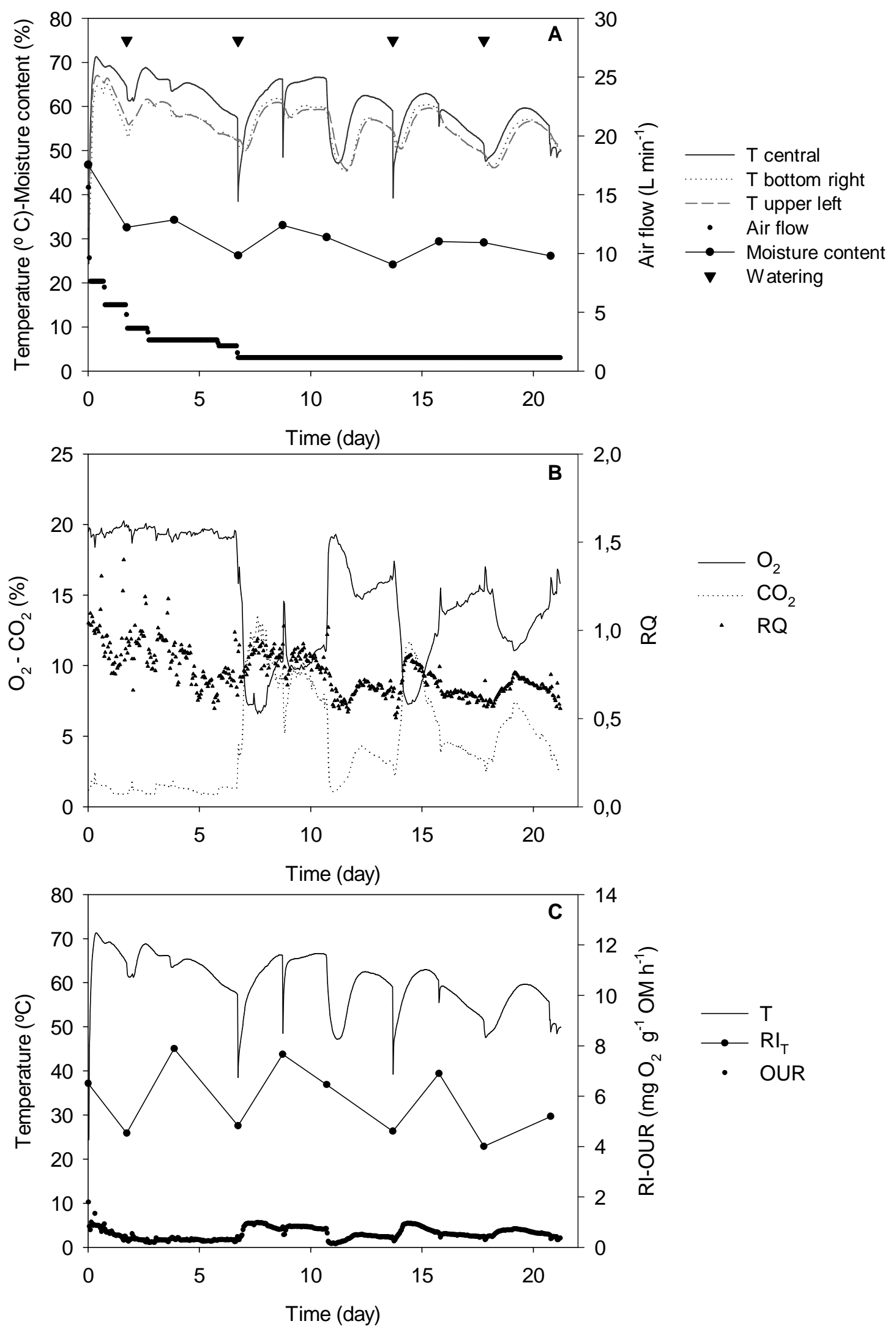
Figure 5.
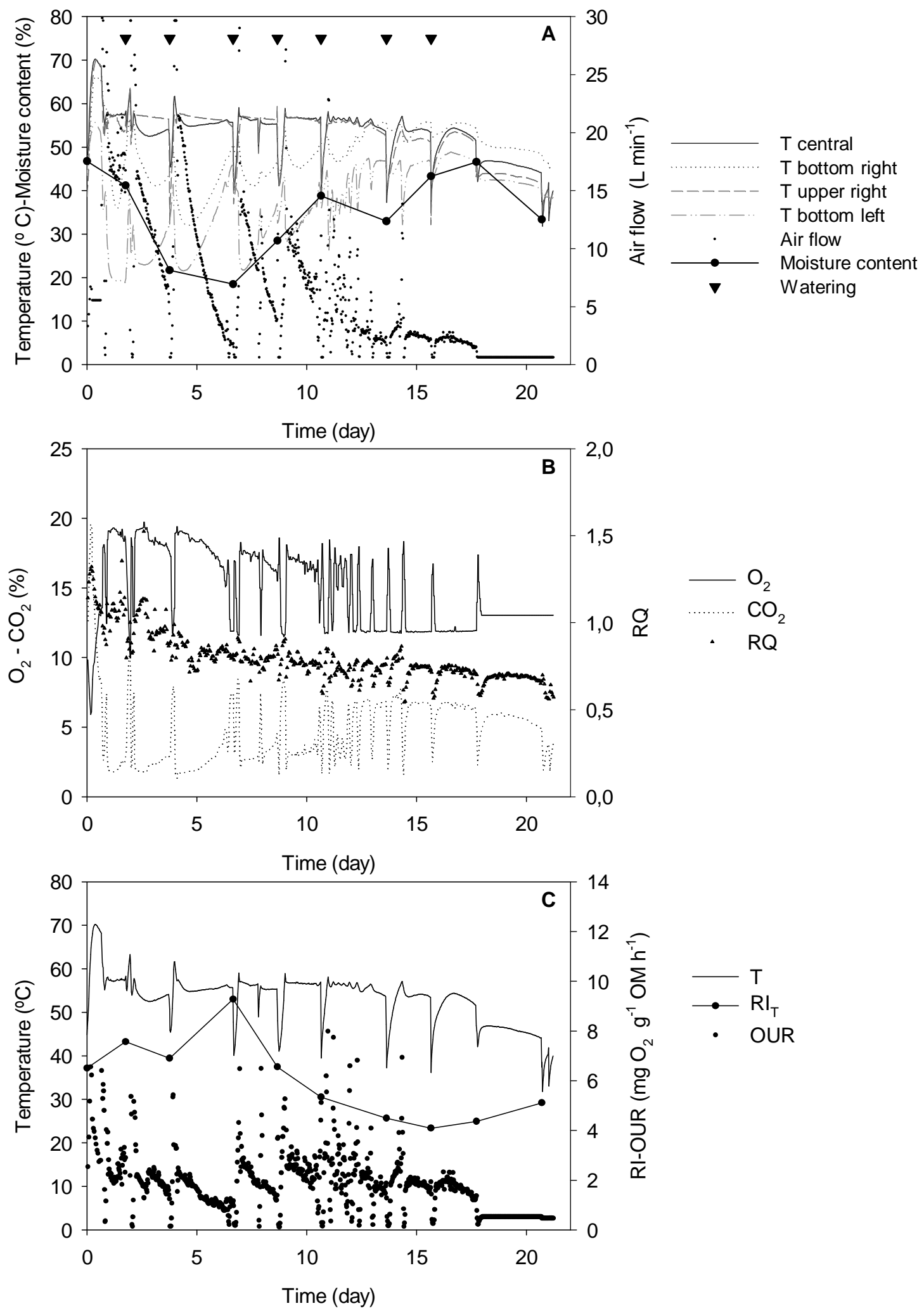